\title{
PENGGUNAAN KITOSAN UNTUK MEMPERPANJANG UMUR SIMPAN BUAH DUKU (Lansium Domesticum Corr)
}

\section{THE USED OF CHITOSAN TO EXTEND \\ THE LANZONES'S (Lansium Domesticum Corr) SHELF LIFE}

\author{
Hesti Nur'aini, S.TP.,MP1, Siska Apriyani, S.TP ${ }^{2}$ \\ 1) Program Studi Teknologi Pertanian Fakultas Pertanian \\ ${ }^{2)}$ Program Studi Teknologi Pangan Fakultas Pertanian \\ Universitas Dehasen Bengkulu \\ nayatha hst@yahoo.co.id
}

\begin{abstract}
ABSTRAK
Duku merupakan buah yang sangat mudah rusak karena kulit buahnya akan berubah menjadi coklat dalam 4 atau 5 hari setelah dipanen sehingga diperlukan metode penanganan pasca panen yang tepat. Salah satu alternatif yang bisa digunakan untuk memperpanjang umur simpan duku dengan biaya relatif ringan adalah pelapisan buah duku dengan kitosan. Pelapis kitosan memiliki kemampuan untuk menunda atau memperlambat proses kematangan dan memperpanjang masa penyimpanan pasca panen. Telah dilakukan penelitian dengan tujuan untuk mengkaji pengaruh kitosan terhadap umur simpan, sifat fisik dan sifat kimia buah duku. Penelitian dilakukan tiga tahap, yaitu tahap pengenceran kitosan dalam asam asetat, tahap pelapisan buah duku dengan larutan kitosan dan tahap analisis. Rancangan penelitian yang digunakan adalah rancangan acak lengkap (RAL), dengan 2 perlakuan yaitu perlakuan konsentrasi kitosan $(0,5 \%, 1,5 \%$ dan 2,5\%) dan perlakuan waktu pencelupan (30 dan 60 menit). Tahap selanjutnya adalah penyimpanan buah duku pada suhu ruang dan analisis pendugaan umur simpan dengan metode konvensional, analisis fisik (tekstur dan bobot buah) serta analisis kimia (kadar air dan tingkat kemanisan).

Hasil penelitian menunjukkan bahwa penggunaan pelapis kitosan mampu memperpanjang umur simpan buah duku hingga 6 hari, dengan perlakuan terbaik menggunakan 1,5\% kitosan dan waktu pencelupan 30 detik. Semakin tinggi konsentrasi kitosan yang diberikan, perubahan pelunakan tekstur dan penurunan bobot buah semakin lambat, dengan nilai tekstur dan bobot buah pada hari ke-6 berturut-turut 225,83 - 234,59 gr/mm dan 19,70 - 23,47 gr per buah. Berdasarkan sifat kimia kadar air dan total padatan terlarut, diketahui bahwa pelapisan kitosan mampu menghambat penurunan kadar air dan total padatan terlarut. Adapun waktu pencelupan 30 dan 60 detik tidak memberikan pengaruh yang nyata. Pengamatan pada hari ke-6 penyimpanan untuk kadar air, berkisar antara $84,44-87,71 \%$, sedangkan total padatan terlarut berkisar antara 17,22 - 20,12\% Brix.
\end{abstract}

Kata kunci : buah duku, kitosan, umur simpan.

\section{ABSTRACT}

Lanzones is a highly perishable fruit because the fruit skin will turn brown within 4 or 5 days after harvest so that the necessary methods of proper post-harvest handling. One alternative that can be used to extend the shelf life lanzones cost is relatively light coating lanzones with chitosan. Chitosan coatings have the ability to delay or slow down the process of extending the maturity and post-harvest storage. Research has been conducted in order to study the effect of chitosan on shelf life, physical and chemical properties of 
lanzones. The study was conducted in three stages namely stage dilution of chitosan in acetic acid, fruit coating stage lanzones with chitosan solution and analysis phase. The study design used was a completely randomized design, with 2 treatment that chitosan treatment concentration ( $0.5 \%, 1.5 \%$ and $2.5 \%)$ and treatment of immersion time (30 and 60 minutes). The next stage is the lanzones fruit storage at room temperature and shelf life prediction analysis with conventional methods, the analysis of physical (texture and fruit weight) and chemical analysis (water content and the level of sweetness). The results showed that the use of chitosan coating to prolong the shelf life of lanzones up to 6 days, with the best treatment using $1.5 \%$ chitosan and immersion time of 30 seconds. The higher concentration of chitosan is given, change the texture softening and decreased fruit weight more slowly, with the value of the texture and weight of fruit on the 6th day in a row from 225.83 to $234.59 \mathrm{~g} / \mathrm{mm}$ and 19.70 to $23.47 \mathrm{~g}$ per fruit. Based on the chemical properties of the water content and total dissolved solids, it is known that chitosan coating could inhibit the decrease in water content and total dissolved solids. The immersion time of 30 and 60 seconds is not a real effect. Observations on the 6th day of storage for water content, ranging between $84.44-87.71 \%$, while the total dissolved solids ranged from 17.22 to $20.12 \%$ Brix.

Keyword : duku, chitosan, shelf life

\section{PENDAHULUAN}

Duku adalah salah satu buah asli yang tumbuh di Indonesia dan merupakan salah satu tanaman berkayu yang hidup selama menahun. Buah duku (Lansium Domesticum Corr) saat ini sudah mulai tersebar luas di belahan benua Asia, yaitu khususnya Asia Tenggara (dari semenanjung Thailand sampai dengan ujung ujung Timur Kalimantan). Dilihat dari komposisi zat gizinya, dalam 100 gram buah duku mengandung energi sebesar 63 kilokalori, protein 1 gram, karbohidrat 16,1 gram, lemak 0,2 gram, kalsium 18 miligram, fosfor 9 miligram, dan zat besi 1 miligram. Selain itu di dalam Buah Duku juga terkandung vitamin A sebanyak 0 IU, vitamin B1 0,05 miligram dan vitamin C 9 miligram (Anonim ${ }^{\mathrm{a}}$, 2012).
Salah satu kendala dalam kegiatan penanganan pasca panen buah duku adalah mudah rusaknya buah duku, terutama terjadinya pencoklatan (browning) pada kulit buah dalam waktu 4 sampai 5 hari setelah dipanen. Anonim (2008) menjelaskan bahwa pencoklatan kulit bisa dihindari dengan menunda pemanenan selama beberapa hari menunggu sampai tandan-tandan lainnya juga matang, namun waktu penundaan yang diberikan tidak berlangsung lama. Buah yang dibiarkan di pohonnya akan tetap mengalami pencoklatan dalam waktu beberapa hari. Salah satu teknologi yang bisa dilakukan untuk memperpanjang umur simpan duku adalah active packaging technology. Namun hal tersebut masih terkendala oleh kepekaan kulit duku terhadap $\mathrm{CO}_{2}$. 
Penelitian active packaging buah duku hingga kurun 4 tahun terakhir ini (Widodo, 2004; 2005 ; Widodo dkk., 2007; Widodo dan Zulferiyenni, 2008 dalam Anonim 2008) telah mampu memperpanjang masa simpan duku 925 hari. Rentang masa simpan ini tampaknya sudah maksimal mengingat pola respirasi duku menunjukkan mulai terjadinya fermentasi antara masa simpan 25-30 hari. Kendala yang dihadapi adalah terjadinya pencoklatan kulit buah duku segera setelah duku dikeluarkan dari kemasannya (diistilahkan sebagai browning pascakemas. Di samping itu, untuk skala industri menengah ke bawah, penggunaan active packaging masih dirasa kurang efektif mengingat perlunya teknologi yang membutuhkan biaya cukup besar. Salah satu alternatif yang bisa digunakan untuk memperpanjang umur simpan duku dengan biaya relatif ringan adalah pelapisan buah duku dengan kitosan.

Kitosan merupakan salah satu jenis polisakarida yang bersifat sebagai penghalang (barrier) yang baik karena dapat membentuk matriks yang kuat dan kompak. Kitosan merupakan turunan dari kitin yang diperoleh dengan cara penghilangan gugus asetil dari kitin dengan menggunakan larutan pekat soda api dengan perlakuan suhu dan lama waktu tertentu serta perbandingan tertentu. Proses selanjutnya adalah pencucian sampai netral, pengeringan, penggilingan, grading dan sortasi serta pengepakan kitosan. Polikationik alami dari kitosan dapat menghambat pertumbuhan kapang Bohria cinerea dan Rhizopus stolonifer pada strawberry (E1 Ghaouth, dkk, 1994).

Kitosan dihasilkan oleh deasetilasi molekul basa $\mathrm{N}$ (nitrogen) parsial pada kitin, yang secara komersil diekstrak dari kulit udang dan kerang. Deasetilasi tersebut berlangsung secara enzimatis dibantu oleh kitin deasetilase. Kitin dan kitosan dapat diperoleh dari limbah hasil laut khususnya kelas krustase seperti udang, kepiting, ketam dan kerang. Limbah udang yang dimanfaatkan umumnya adalah kulit dan kepalanya, sedangkan kitin dari rajungan diperoleh dari karapasnya. Kandungan kitin kulit udang mencapai $40-60 \%$ dari berat kering tubuhnya tergantung dari jenis dan spesiesnya. Sedangkan pada kulit rajungan kitinnya dapat mencapai 12,5 $15 \%$. Banyaknya permintaan akan kitosan dipicu fakta akan keunikan karakteristik biologisnya seperti biodegradabilitas, biokompabilitas, dan tidak beracun, sehingga memungkinkan aplikasi di berbagai bidang. Meskipun sangat berlimpah di alam, namun pemanfaatan kitosan baru berkembang pada dua dekade terakhir. Kitosan banyak 
digunakan di bidang pangan, farmasi, medis, tekstil, pertanian, dan industri lain misalnya purifikasi limbah Kitosan menarik banyak perhatian karena menunjukkan aktivitas antimikrobial terhadap fungi, bakteri, dan virus. Aplikasi komersil dari aktivitas komersil kitosan antara lain penggunaan sebagai pengawet makanan, obat anti infeksi, dan tekstil bebas mikroba (Anonim, 2011)

Pelapis kitosan memiliki kemampuan untuk menunda atau memperlambat proses kematangan dan memperpanjang masa penyimpanan pasca panen. Pelapis kitosan yang seperti itu memiliki kemampuan untuk membatasi ruang hampa dalam jaringan dan bersifat sebagai anti jamur (El Ghaouth et al. 1994). Penelitian Widodo dan Zulferiyenni (2008) dalam Anonim (2008), menerangkan bahwa penggunaan active packaging dengan tambahan perlakuan pelapisan duku dengan kitosan mampu memperlambat proses pencoklatan kulit dari awalnya 10 detik hingga menjadi 24,46 menit. Berdasarkan uraian di atas, perlu dilakukan penelitian tentang pengaruh penggunaan kitosan dalam upaya memperpanjang umur simpan dan daya terima konsumen terhadap buah duku.

Tujuan penelitian ini adalah untuk mengkaji pengaruh pelapisan kitosan dalam memperpanjang umur simpan buah duku dan mengkarakterisasi pengaruh pelapisan kitosan terhadap sifat fisik dan kimia buah duku.

\section{METODOLOGI}

\section{Bahan dan Alat}

Bahan yang digunakan pada penelitian adalah buah duku, yang diperoleh dari petani di daerah Arga Makmur Bengkulu Utara, kitosan yang dibeli di Laboraturium Fakultas Pertanian Universitas Dehasen Bengkulu, bahanbahan kimia untuk analisa dan aquades. Adapun alat yang digunakan pada penelitian ini adalah penetrometer, refraktometer dan alat-alat untuk analisis fisik, kimia dan uji sensoris.

\section{Metode}

Penelitian dilaksanakan dalam tiga tahap, yaitu tahap pelarutan/pengenceran kitosan ke dalam asam asetat $1 \%$, tahap pelapisan buah duku menggunakan larutan kitosan dengan variasi perlakuan konsentrasi kitosan $0,5 \%, 1,5 \%$ dan 2,5\% selama 30 detik dan 60 detik, tahap penyimpanan serta tahap analisis. Analisis yang dilakukan dalam penelitian ini meliputi analisis pendugaan umur simpan buah duku, analisis fisik (tekstur dan bobot buah) dan analisis kimia (kadar air dan tingkat kemanisan buah). Rancangan percobaan yang digunakan adalah Rancangan Acak Lengkap, 
menggunakan percobaan faktorial, yaitu faktor konsentrasi kitosan dan waktu pencelupan. Apabila terdapat perbedaan yang nyata antar perlakuan, dilanjutkan dengan uji Duncan's Multiple Range Test (DMRT) pada rentang kepercayaan atau uji beda nyata terkecil $5 \%$.

\section{HASIL DAN PEMBAHASAN Karakteristik Duku}

Pengamatan terhadap karakteristik duku sebagai bahan dasar perlu dilakukan untuk mengidentifikasi sifat-sifat fisik dan kimia buah duku sebagai bahan utama yang akan diteliti, sehingga bisa diamati perubahan-perubahan yang terjadi selama penyimpanan. Hasil pengukuran karakteristik buah duku yang diteliti disajikan pada Tabel 1.

Buah duku yang digunakan dalam penelitian ini mempunyai karakteristik yang baik, sesuai dengan hasil penelitian Yusnaidar (2003), yang menyatakan bahwa kadar air buah duku berkisar antara $86-88 \%$ dan total padatan terlarut berkisar antara $18-24^{\circ}$ Brix. Adapun sesuai dengan Standar Nasional Indonesia No.6151 Tahun 2009 tentang Duku, bobot buah untuk buah duku yang terukur sebesar 25,48 gram per buah, termasuk ke dalam kualitas ke-3 (sedang) (Anonim, 2009).

Buah duku yang digunakan dalam penelitian ini mempunyai karakteristik yang baik, sesuai dengan hasil penelitian Yusnaidar (2003), yang menyatakan bahwa kadar air buah duku berkisar antara $86-88 \%$ dan total padatan terlarut berkisar antara $18-24^{\circ}$ Brix. Adapun sesuai dengan Standar Nasional Indonesia No.6151 Tahun 2009 tentang Duku, bobot buah untuk buah duku yang terukur sebesar 25,48 gram per buah, termasuk ke dalam kualitas ke-3 (sedang) (Anonim, 2009).

\section{Umur Simpan Buah Duku}

Pendugaan umur simpan buah duku dilakukan menggunakan metode konvensional, melalui pengujian organoleptik buah duku yang disimpan pada suhu ruang yang dilakukan setiap hari dimulai dari hari ke-0 dan diakhiri ketika panelis menyatakan sampel buah duku tidak layak untuk dikonsumsi. Panelis yang digunakan adalah 20 orang panelis terlatih dengan parameter yang diamati meliputi warna kulit, warna daging, rasa dan tekstur. Batas penerimaan konsumen adalah skor 3 (netral). 
Tabel 1. Karakteristik Duku

\begin{tabular}{|l|l|l|c|}
\hline No. & \multicolumn{1}{|c|}{ Komponen } & Satuan & Hasil Pengukuran \\
\hline 1. & Kadar Air & \% & 88,62 \\
\hline 2. & Total Padatan Terlarut & ${ }^{0}$ Brix & 17,23 \\
\hline 3. & Tekstur & gr/mm & 219,22 \\
\hline 4. & Bobot Buah & gram $/ \mathrm{bh}$ & 25,48 \\
\hline
\end{tabular}

Ket : Hasil pengukuran terhadap sampel buah duku pada hari ke-0

Nilai Organoleptik Warna Kulit Duku

Warna merupakan salah satu atribut mutu yang sangat penting bagi produk olahan pangan, yang mendapatkan perhatian cukup besar oleh para pengusaha industri pengolahan pangan. Bahwa penentuan mutu bahan pangan pada umumnya sangat bergantung pada beberapa faktor, di antaranya cita rasa, warna, tekstur dan nilai gizinya. Walaupun warna kurang berhubungan dengan niai gizi, kenyataan membuktikan bahwa sebelum faktorfaktor lain dipertimbangkan, secara visual faktor warna tampil lebih dahulu dan kadang-kadang sangat menentukan. Suatu bahan yang dinilai bergizi, enak dan teksturnya sangat baik kurang disukai konsumen apabila memiliki warna yang tidak sedap dipandang atau memberi kesan telah menyimpang dari warna yang seharusnya (Winarno, 2004), begitu pula pada buah duku. Warna kulit buah duku sangat mempengaruhi penerimaan konsumen. Nilai organoleptik warna kulit buah duku selama waktu penyimpanan disajikan pada Gambar 1.

Hasil penilaian organoleptik terhadap warna kulit duku menunjukkan kecenderungan bahwa semakin lama waktu penyimpanan, tingkat kesukaan konsumen semakin menurun. Perlakuan pencelupan ke dalam kitosan dan lama pencelupan juga memberikan pengaruh terhadap umur simpan buah duku, yang ditunjukkan dengan semakin tinggi konsentrasi kitosan dan waktu pencelupan, maka tingkat kesukaan panelis terhadap warna kulit buah duku semakin baik. Warna kulit buah duku disukai sampai hari ke-5 penyimpanan, untuk perlakuan $0,5 \%$ kitosan dan pencelupan selama 30 detik, sedangkan untuk sampel dengan perlakuan lain, masih bisa bertahan hingga hari ke tujuh. 


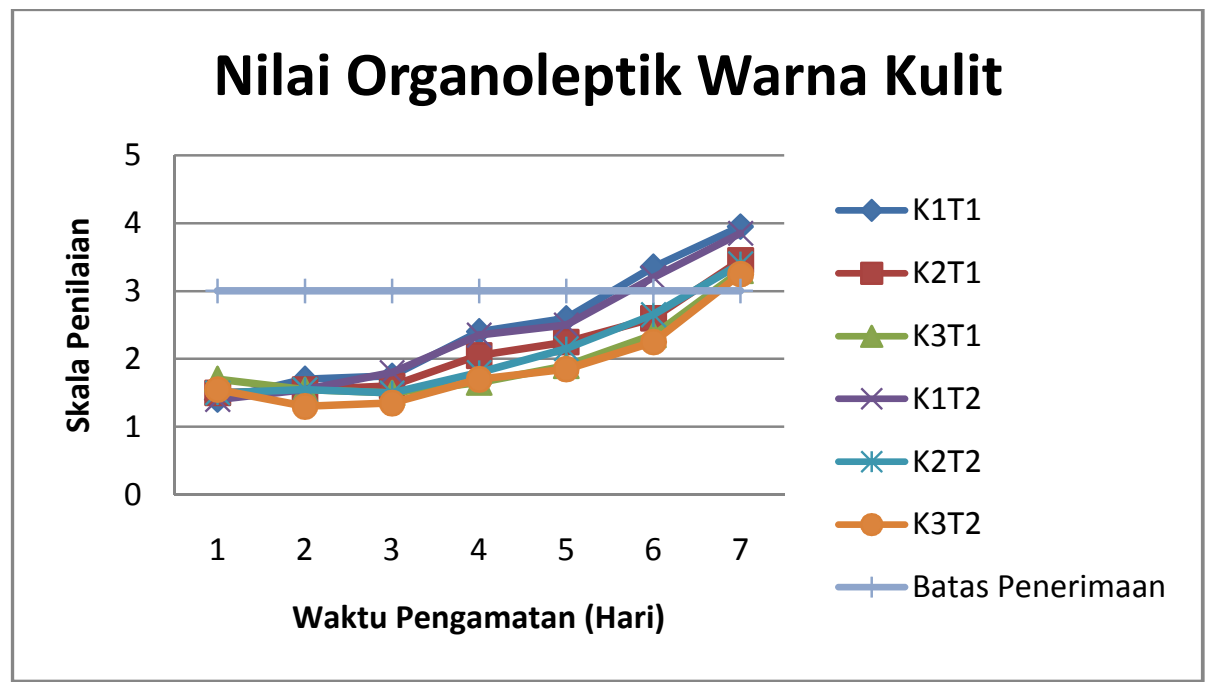

Ket : Skala Penilaian : 1. Sangat Suka; 2. Suka; 3. Netral; 4. Tidak Suka; 5. Sangat Tidak Suka Kode Sampel : $\quad$ K1T1 : 0,5\% Kitosan,30 dtk, K2T1: 1,5\%,30 dtk, K3T1: 2,5\%,30 dtk K1T2 : 0,5\% Kitosan,60 dtk, K2T2: 1,5\%,60 dtk, K3T2: 2,5\%,60 dtk

\section{Gambar 1. Grafik Nilai Organoleptik Warna Kulit Buah Duku selama Penyimpanan}

Perubahan warna kulit buah duku teebentuk karena adanya reaksi pencoklatan enzimatis yang secara alami terjadi pada komoditas hasil pertanian yang mengandung polifenol. Semakin lama waktu penyimpanan, kerusakan jaringan kulit yang terjadi akibat proses respirasi dan transpirasi menyebabkan adanya kontak antara senyawa polifenol dengan oksigen. Dengan bantuan enzim polifenol oksidase, reaksi pencoklatan enzimatis segera terjadi yang menghasilkan senyawa quinon berwarna coklat (Winarno,F.G, 2002; Muchtadi, 1992).
Nilai Organoleptik Warna Daging Buah Duku

Grafik penilaian uji hedonik warna daging buah disajikan pada Gambar 2 yang menunjukkan kecenderungan bahwa perlakuan pencelupan ke dalam larutan kitosan berpengaruh terhadap penerimaan konsumen. Perlakuan pencelupan buah duku ke dalam 0,5\% dan 1,5\% larutan kitosan selama 30 menit masih disukai sampai hari ke 4, sementara untuk perlakuan lain bisa bertahan hingga 5 hari. 


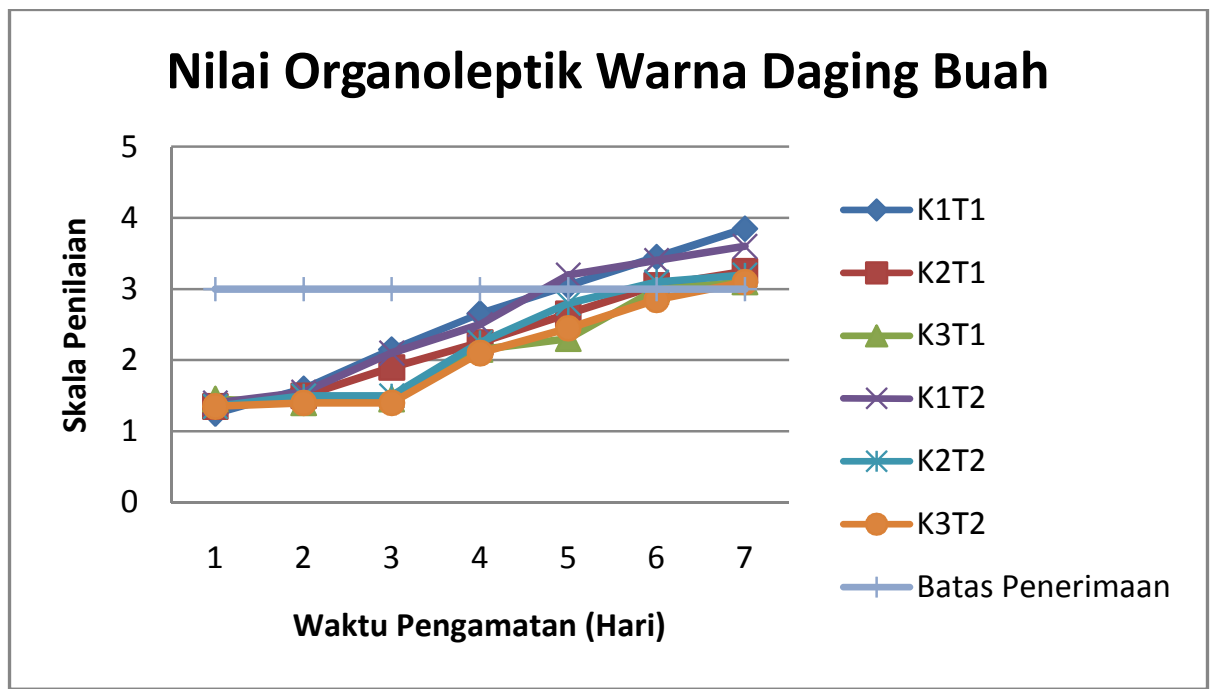

Ket : Skala Penilaian : 1. Sangat Suka; 2. Suka; 3. Netral; 4. Tidak Suka; 5. Sangat Tidak Suka Kode Sampel : $\quad$ K1T1 : 0,5\% Kitosan,30 dtk, K2T1: 1,5\%,30 dtk, K3T1: 2,5\%,30 dtk K1T2 : 0,5\% Kitosan, 60 dtk, K2T2: 1,5\%,60 dtk, K3T2: 2,5\%,60 dtk

\section{Gambar 2.Grafik Nilai Organoleptik Warna Daging Buah Duku selama Penyimpanan}

Perubahan-perubahan yang terjadi selama penyimpanan akibat proses fisiologis dan mikrobiologis menyebabkan kerusakan jaringan kulit dan daging buah duku. Prabawati et al. (1991) mendapatkan cendawan perusak pada kulit buah duku mampu menghidrolisa selulosa murni. Aktifitas cendawan ini menyebabkan kerusakan pada jaringan kulit yang akan meningkatkan transpirasi daging buah. Akibatnya, kerusakan daging buah lebih cepat terjadi.

\section{Nilai Organoleptik Rasa Duku}

Penilaian uji organoleptik terhadap rasa buah duku ditampilkan pada Gambar 3, yang menunjukkan kecenderungan bahwa perlakuan pencelupan dalam larutan kitosan $0,5 \%, \quad 1,5 \%$ dan 2,5 selama 30 detik bisa diterima oleh panelis hingga hari ke-5, sementara untuk perlakuan pencelupan kitosan selama 60 detik masih bertahan hingga 6 hari.

Penilaian rasa buah duku sangat erat kaitannya dengan komponen penyusun yang ada di dalam buah tersebut. Proses fisiologis dan mikrobiologis yang terjadi selama penyimpanan akan mendegradasi senyawa-senyawa pembentuk cita rasa yang ada di dalam buah. Di sisi lain, aktivitas mikrobiologis memunculkan senyawa baru yang memberikan pengaruh negatif terhadap cita rasa buah duku, seperti munculnya cendawan, aroma tidak sedap dan lain-lain (Winarno,F.G dan M.Aman, 2002; Prabawati, S, dkk, 1991). 


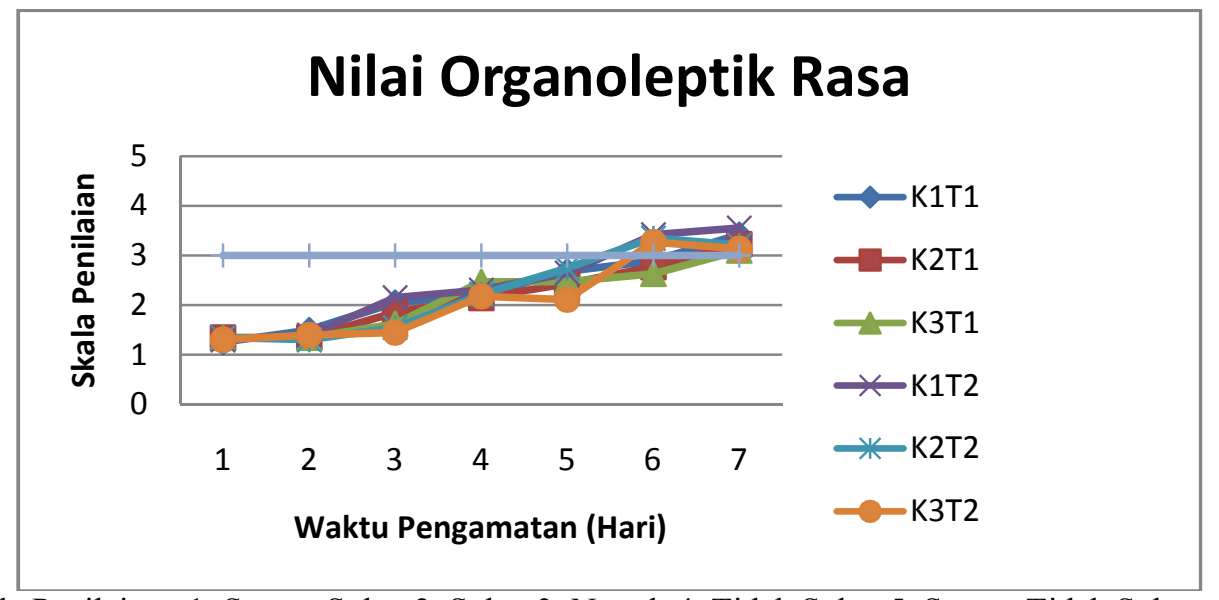

Ket : Skala Penilaian : 1. Sangat Suka; 2. Suka; 3. Netral; 4. Tidak Suka; 5. Sangat Tidak Suka Kode Sampel : $\quad$ K1T1 : 0,5\% Kitosan,30 dtk, K2T1: 1,5\%,30 dtk, K3T1: 2,5\%,30 dtk K1T2 : 0,5\% Kitosan,60 dtk, K2T2: 1,5\%,60 dtk, K3T2: 2,5\%,60 dtk

Gambar 3. Grafik Nilai Organoleptik Rasa Buah Duku selama Penyimpanan

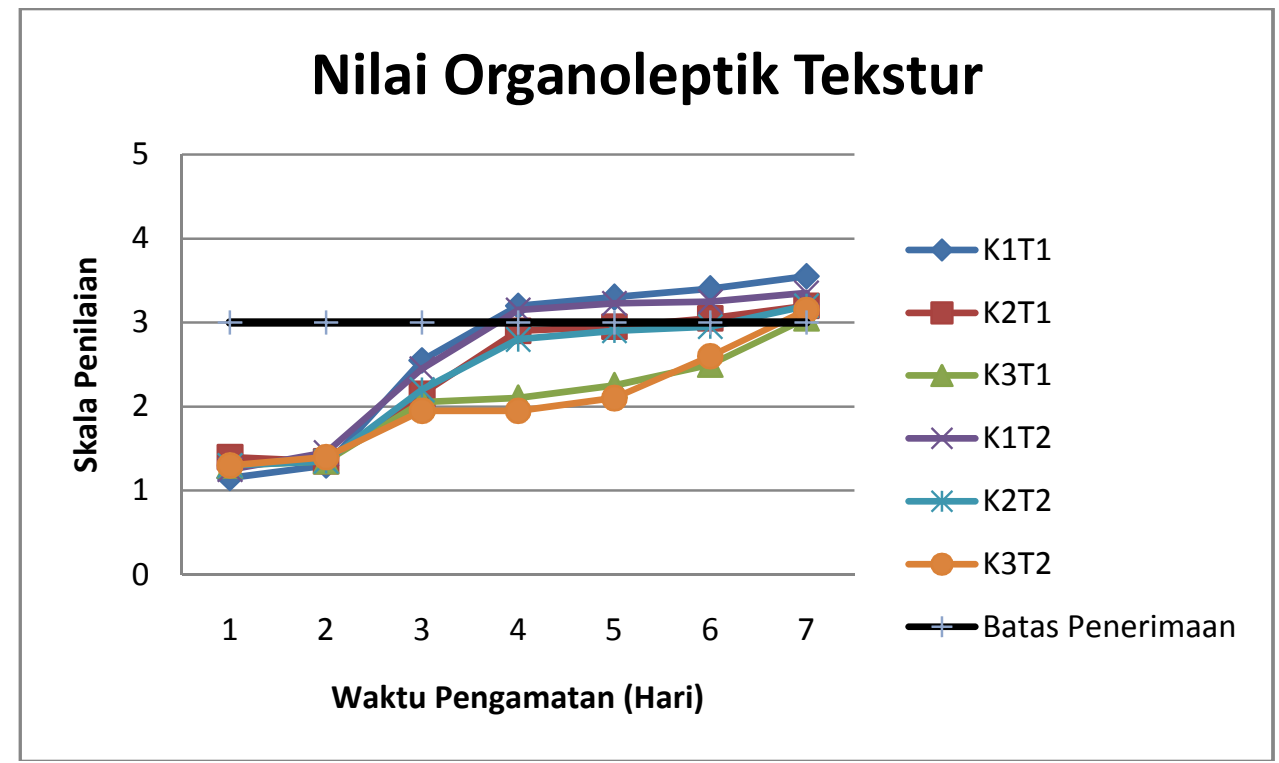

Ket : Skala Penilaian : 1. Sangat Suka; 2. Suka; 3. Netral; 4. Tidak Suka; 5. Sangat Tidak Suka Kode Sampel : $\quad$ K1T1 : 0,5\% Kitosan,30 dtk, K2T1: 1,5\%,30 dtk, K3T1: 2,5\%,30 dtk K1T2 : 0,5\% Kitosan,60 dtk, K2T2: 1,5\%,60 dtk, K3T2: 2,5\%,60 dtk

\section{Gambar 4. Grafik Nilai Organoleptik}

Tekstur Buah Duku selama Penyimpanan

\section{Nilai Organoleptik Tekstur Duku}

Penilaian tekstur buah duku dilakukan pada daging buah, yang hasilnya disajikan pada Gambar 5.4. Batas penerimaan terhadap tekstur buah duku untuk perlakuan pencelupan ke dalam $0,5 \%$ dan $1,5 \%$ selama 30 detik adalah selama 3 hari, sementara untuk perlakuan yang lain masih bisa diterima hingga 5 hari. 
Transpirasi yang terjadi selama proses fisiologis mengakibatkan berkurangnya kadar air yang terdapat dalam buah duku. Hal ini berakibat terhadap perubahan tekstur buah yang tidak segar lagi. Selain itu, reaksi mikrobiologis bisa merusak jaringan daging buah sehingga terjadi penurunan kualitas tekstur daging buah (Kartasapoetra, A.G, 1999; Asni.N, 2004).

Berdasarkan uji organoleptik buah duku, warna daging buah serta rasa ditentukan menjadi titik kritis penilaian. Warna daging buah menjadi kesan yang pertama muncul ketika panelis atau konsumen akan menilai serta uji rasa merupakan justifikasi dari penampilan luar. Pada uji kesukaan warna daging buah dan rasa, perlakuan pencelupan buah duku ke dalam kitosan $0,5 \%$ dan $1,5 \%$ selama 30 detik masih disukai hingga penyimpnan selama 4 hari, sementara untuk perlakuan lain, bertahan hingga 5 hari. Sementara itu, penilaian uji organoleptik terhadap rasa buah duku menunjukkan kecenderungan bahwa perlakuan pencelupan dalam larutan kitosan 0,5\%, 1,5\% dan 2,5 selama 30 detik bisa diterima oleh panelis hingga hari ke-5, sementara untuk perlakuan pencelupan kitosan selama 60 detik masih bertahan hingga 6 hari. Berdasarkan hasil pengamatan tersebut, dapat disimpulkan bahwa umur simpan buah duku yang dilapisi dengan kitosan secara umum bisa bertahan selama 6 hari. Sebenarnya umur simpan duku yang dilapisi dengan kitosan masih dapat bertahan hingga 7 hari, karena cendawan perusak pasca panen mulai muncul pada hari ke-7 sehingga produk tidak dapat dikonsumsi lagi. Tetapi tampaknya panelis mulai tidak menyukai duku setelah hari ke-6 penyimpanan, karena pada permukaan buah mulai tampak terdapat bintik-bintik air yang disebabkan laju respirasi yang cukup tinggi. Uap air yang dikeluarkan akibat proses respirasi serta transpirasi menyebabkan tampilan warna kulit menjadi tidak menarik (kecoklatan dan keriput), di samping perubahan warna biji yang semula putih kekuningan menjadi coklat kehitaman.

\section{Karakteristik Fisik Buah Duku selama Penyimpanan}

\section{Analisis Tekstur Buah Duku}

Hasil pengamatan tekstur buah duku dengan pelapisan kitosan ditampilkan pada Tabel 2, yang menunjukkan bahwa secara umum perlakuan konsentrasi kitosan berpengaruh nyata terhadap tekstur buah, sedangkan lama pencelupan tidak berpengaruh nyata. Semakin tinggi angka tekstur, menunjukkan semakin lunak bahan yang diukur. 
Tabel 2. Tekstur (gr/mm) Buah Duku pada Hari ke-6

\begin{tabular}{|l|c|c|c|}
\hline \multirow{2}{*}{ Waktu Pencelupan } & \multicolumn{3}{|c|}{ Konsentrasi Kitosan (\%) } \\
\cline { 2 - 4 } & 0,5 & 1,5 & 2,5 \\
\hline 30 detik & $237,10 \mathrm{a}$ & $228,23 \mathrm{c}$ & $226,40 \mathrm{~d}$ \\
\hline 60 detik & $234,59 \mathrm{~b}$ & $228,08 \mathrm{c}$ & $225,83 \mathrm{~d}$ \\
\hline Kontrol (Hari ke-0) & 219,22 & & \\
\hline
\end{tabular}

Angka yang diikuti oleh huruf yang berbeda menunjukkan perbedaan yang nyata berdasarkan uji Duncan's pada $\alpha 5 \%$.

Perubahan tekstur daging buah duku sangat erat kaitannya dengan tingkat ketegaran daging buah tersebut, yang dipengaruhi oleh reaksi fisiologis dan mikrobiologis selama penyimpanan (Muchtadi.D, 1992; Kartasapoetra, A.G, 1999). Reaksi respirasi yang terjadi pada buah duku memiliki pola respirasi klimakterik (Adnan, 2006; Er.B. Pantastico, 1993), sehingga semakin lama waktu simpan, tingkat kerusakan buah semakin cepat. Dari segi tekstur, semakin lama waktu simpan, daging buah duku menjadi semakin lembek dan keriput, yang terjadi akibat adanya transpirasi yang diawali pada kulit kemudian merambah ke dalam daging buah. Penggunaan kitosan sebagai bahan pelapis bisa menghambat laju respirasi dan transpirasi, sehingga penurunan kualitas buah dari segi tekstur bisa ditekan. Hal ini senada dengan hasil penelitian Hardjito (2006) yang menyatakan bahwa penggunaan pelapisan kitosan dengan konsentrasi 1,5 $\%$ pada buah strawberry yang disimpan pada suhu $13^{\circ} \mathrm{C}$ terbukti mampu menekan kerusakan buah selama penyimpanan. Hasil penelitian tersebut menunjukkan bahwa strawberry yang diberi pelapisan kitosan lebih tinggi tingkat kekerasannya, produksi antosianin dan total asamnya daripada strawberry tanpa pelapisan kitosan maupun strawberry yang diberi fungisida. Karena kitosan mampu berfungsi sebagai anti fungal sehingga buah-buahan yang dilapisi dengan kitosan tidak mudah rusak selama pengangkutan dan penyimpanan. Penelitian lain menyebutkan bahwa pelapisan kitosan pada salak pondoh dengan konsentrasi 0,5 dan 1,0\% mampu mempertahankan umur simpan salak pondoh sampai hari ke-15 (Maulida.R, 2010).

\section{Analisis Bobot Buah Duku}

Bobot buah duku merupakan salah satu parameter yang menentukan standar mutu buah. Menurut SNI No. 6151 Tahun 2009, berdasarkan bobotnya, buah duku dikategorikan menjadi 5 (lima) tingkatan mutu (Tabel 4). 
Tabel 3. Bobot Buah Duku (gr) pada Hari ke-6

\begin{tabular}{|l|l|c|c|}
\hline \multirow{2}{*}{$\begin{array}{c}\text { Waktu } \\
\text { Pencelupan }\end{array}$} & \multicolumn{3}{|c|}{ Konsentrasi Kitosan (\%) } \\
\cline { 2 - 4 } & 0,5 & 1,5 & 2,5 \\
\hline 30 detik & $19,70 \mathrm{c}$ & $21,65 \mathrm{~b}$ & $23,47 \mathrm{a}$ \\
\hline 60 detik & $19,85 \mathrm{c}$ & $22,22 \mathrm{~b}$ & $23,42 \mathrm{a}$ \\
\hline Kontrol & 25,48 & & \\
\hline
\end{tabular}

Angka yang diikuti oleh huruf yang berbeda menunjukkan perbedaan yang nyata berdasarkan uji Duncan's pada $\alpha 5 \%$

Tabel 4. Kode Ukuran Berdasarkan Bobot (SNI No.6151 Tahun 2009)

\begin{tabular}{|c|c|}
\hline Kode Ukuran & Bobot (gram) \\
\hline 1 & $27,5-30.0$ \\
\hline 2 & $25,9-27,4$ \\
\hline 3 & $22,5-25,8$ \\
\hline 4 & $19,9-22,4$ \\
\hline 5 & $15,0-19,8$ \\
\hline
\end{tabular}

Sumber : BSN (2000)

Bobot buah duku untuk kontrol yang diukur pada hari ke-0 sebesar 25,48 gram per buah, termasuk ke dalam kualitas ke3 (sedang) (Anonim, 2009). Adapun hasil pengukuran bobot buah duku yang dilapisi dengan kitosan, pada hari ke-6 ditunjukkan pada Tabel 5.3.Perlakuan pelapisan kitosan dengan variasi konsentrasi $\quad 0,5 \%, \quad 1,5 \%$ dan $\quad 2,5 \%$ memberikan pengaruh yang nyata terhadap perubahan bobot buah duku pada hari ke-6, sedangkan perlakuan waktu pencelupan tidak memberikan pengaruh yang nyata. Semakin tingi konsentrasi larutan pelapis kitosan yang diberikan, maka penurunan bobot buah duku pada hari ke-6 semakin kecil. Hal ini erat kaitannya dengan peranan kitosan dalam menghambat laju reaksi respirasi dan transpirasi yang bisa menurunkan kualitas buah. Hasil penelitian Widodo
(2005) melaporkan bahwa terjadi penyusutan bobot buah sebesar $15.79 \%$ pada buah duku yang disimpan selama 3 hari. Susut bobot tersebut dapat ditekan menjadi sekitar 1.51-2.89\% jika buah duku disimpan dalam chamber serta diberi bahan penyerap. Menurut Hirano (1996) kitosan diketahui mempunyai kemampuan untuk membentuk gel, film dan fiber, karena berat molekulnya yang tinggi dan solubilitasnya dalam larutan asam encer, sehingga mampu menghambat laju reaksi fisiologis dan mikrobiologis penyebab kerusakan buah.

\section{Karakteristik Kimia Buah Duku selama Penyimpanan}

Analisis Kadar Air (\%) Buah Duku

Kadar air merupakan salah satu parameter bahan pangan yang paling menentukan karakter dan umur simpan. 
Secara umum, semakin tinggi kadar air suatu bahan, maka makin singkat umur simpan bahan pangan tersebut (Winarno, F.G, 2004).

Kadar air daging buah duku pada hari ke6 penyimpanan berdasarkan perlakuan penelitian disajikan pada Tabel 5 . Perubahan kadar air pada daging buah duku sangat dipengaruhi oleh terjadinya reaksi fisiologis terutama transpirasi. Semakin lama waktu penyimpanan, kadar air daging buah akan menjadi berkurang. Keadaan berair yang ditemui di sekitar permukaan daging dan kulit buah adalah sebagai akibat reaksi respirasi dan aktivitas mikroorganisme. Hasil penelitian menunjukkan bahwa semakin tinggi konsentrasi pelapis larutan kitosan, maka penurunan kadar air daging buah semakin kecil, sementara waktu pencelupan 30 dan 60 detik, secara umum tidak memberikan pengaruh yang nyata kecuali pada perlakuan pelapisan 1,5\% larutan kitosan. Hal ini disebabkan karena kemampuan kitosan dalam melapisi jaringan kulit buah, sehingga proses transpirasi bisa dihambat (Hirano,L., 1996), dibuktikan dengan selisih kadar air antara kontrol pada hari ke-0 pengamatan $(88,62 \%)$ dengan kadar air sampel pada setiap perlakuan.

\section{Analisis Total Padatan Terlarut ( ${ }^{0}$ Brix)} Buah Duku

Total padatan terlarut atau brix adalah jumlah zat padat semu yang larut (dalam gr) setiap 100 gr larutan yang dengan kata lain menunjukkan jumlah gula, pati, garam-garam dan zat organik yang terkandung di dalam suatu bahan (Kuswuri,R.,2012) Hasil pengamatan menunjukkan bahwa pada penyimpanan hari ke-6, semakin tinggi konsentrasi larutan kitosan yang diberikan, total padatan terlarut daging buah duku semakin besar (Tabel 6). adapun waktu pencelupan 30 dan 60 detik hanya memberikan pengaruh yang nyata pada perlakuan 1,5\% larutan kitosan.

Tabel 5. Kadar Air (\%) Buah Duku pada Hari ke-6

\begin{tabular}{|l|l|c|c|}
\hline \multirow{2}{*}{ Waktu Pencelupan } & \multicolumn{3}{|c|}{ Konsentrasi Kitosan (\%) } \\
\cline { 2 - 4 } & 0,5 & 1,5 & 2,5 \\
\hline 30 detik & $84,44 \mathrm{c}$ & $84,46 \mathrm{c}$ & $87,38 \mathrm{a}$ \\
\hline 60 detik & $84,56 \mathrm{c}$ & $86,42 \mathrm{~b}$ & $87,71 \mathrm{a}$ \\
\hline Kontrol Hari ke-0 & 88,62 & & \\
\hline
\end{tabular}

Angka yang diikuti oleh huruf yang berbeda menunjukkan perbedaan yang nyata berdasarkan uji Duncan's pada $\alpha 5 \%$ 
Tabel 6. Total Padatan Terlarut ( ${ }^{\circ}$ Brix) Buah Duku pada Hari ke-6

\begin{tabular}{|l|l|c|c|}
\hline \multirow{2}{*}{$\begin{array}{c}\text { Waktu } \\
\text { Pencelupan }\end{array}$} & \multicolumn{3}{|c|}{ Konsentrasi Kitosan (\%) } \\
\cline { 2 - 4 } 30 detik & 0,5 & 1,5 & 2,5 \\
\hline 60 detik & $20,00 \mathrm{a}$ & $18,46 \mathrm{~b}$ & $17,44 \mathrm{~d}$ \\
\hline Kontrol Hari ke-0 & $20,12 \mathrm{a}$ & $18,43 \mathrm{~b}$ & $17,81 \mathrm{c}$ \\
\hline
\end{tabular}

Angka yang diikuti oleh huruf yang berbeda menunjukkan perbedaan yang nyata berdasarkan uji Duncan's pada $\alpha 5 \%$

Pada umumnya total padatan terlarut buah mengalami penurunan selama penyimpanan. Peningkatan total padatan terlarut selama penyimpanan mungkin terjadi karena transpirasi buah yang menyebabkan kadar air buah menurun (Adnan, 2006). Selain itu, peningkatan total padatan terlarut tersebut tampaknya berhubungan dengan aktifitas mikroorganisme. Prabawati, dkk (1991) mendapatkan cendawan perusak pada kulit buah duku mampu menghidrolisa selulosa murni. Aktivitas cendawan ini menyebabkan peningkatan kadar gula total pada kulit buah duku. Di sisi lain, Widodo (2005) melaporkan bahwa terjadi penyusutan bobot buah sebesar 15.79\% pada buah duku yang disimpan selama 3 hari. Susut bobot tersebut dapat ditekan menjadi sekitar 1.51-2.89\% jika buah duku disimpan dalam chamber serta diberi bahan penyerapan.

\section{SIMPULAN}

Penggunaan pelapis kitosan mampu memperpanjang umur simpan buah duku hingga 6 hari, dengan perlakuan terbaik menggunakan 1,5\% kitosan dan waktu pencelupan 30 detik. Semakin tinggi konsentrasi kitosan yang diberikan, perubahan pelunakan tekstur dan penurunan bobot buah semakin lambat, sedangkan waktu pencelupan 30 dan 60 detik secara umum tidak memberikan pengaruh yang nyata. Berdasarkan sifat kimia, yaitu kadar air dan total padatan terlarut, diketahui bahwa pelapisan kitosan mampu menghambat penurunan kadar air dan total padatan terlarut. Adapun waktu pencelupan 30 dan 60 detik tidak memberikan pengaruh yang nyata.

\section{DAFTAR PUSTAKA}

Anonim. 2008. Active Packaging untuk Buah Duku. http://smarters06.blogspot.com/20 08/11/active-packaging-untukbuah-duku.html

Anonim,.2011. Kitin. http://id.wikipedia.org/wiki/Kitin. diakses 24 Maret 2013.

Anonim $^{\mathrm{a}}$. 2012.

Duku. http://id.wikipedia.org/wiki/Duku, .diakses 24 Maret 2013.

Anonim $^{\text {b. 2012. Komposisi Nutrisi }}$ Bahan Makanan. http://keju.blogspot.com/1970/01/ isi-kandungan-gizi-buah-duku- 
komposisi-nutrisi-bahan-

makanan.html, diakses 24 Maret 2013.

Anonim $^{c}$. 2012. Manfaat dan Khasiat Buah Duku. http://e-lifestylenews. Blogspot. com/2012/09/6manfaat-dan-khasiat-buah-dukuuntuk.html. diakses 24 Maret 2013.

Adnan, 2006, Penyimpanan Buah Duku

Terolah Minimal dalam Kemasan Atmosfir Termodifikasi, Tesis, Sekolah Pasca Sarjana, IPB, Bogor.

Asni, N., 2004, Upaya Memperpanjang

Masa Simpan Duku, Balai

Pengkajian Teknologi Pertanian Jambi, Jambi.

Badan Standarisasi Nasional, 2009, Standar Nasional Indonesia No.6121, Duku, Badan Standarisasi Nasional, Jakarta.

Baker. LG (2007). "Chitosan, the Deacetylated Form of Chitin, is Necessary for Cell Wall integrity in Cryptococcus neoformans". "Eukaryotic Cell".

Bappenas. 2000. Budidaya dan Pasca Panen Duku. Sistem Informasi Manajemen Pembangunan di Perdesaan. BAPPENAS, Jakarta.

El Ghaouth A, Arul J, Ponnampalam R, oule M (1991) Chitosan Coating Effect on Storability and Quality of Fresh Strawberries. J Food Sci 56: 1618-1620.

Er.B. Pantastico, (Ed) Fisiologi Pasca, Penanganan dan Pemanfaatan Buah-buahan dan Sayur-sayuran Tropika dan Subtropika, Terjemahan, Kamarijani, Gajah Mada University Press, Hal. 136159.

Kusnandar. Feri. 2010. Pendugaan Umur Simpan Produk Pangan dengan Metode Accelerated Shelf-life Testing (ASLT). Seafast Center. IPB.

Hirano, S. 1996. Chitin Biotechnology Applications. Biotechnology Annual, Rev.
Hardjito, L. 2006. Aplikasi Kitosan Sebagai Bahan Tambahan Makanan dan Pengawet. Prosiding Seminar Nasional Kitin-Kitosan. Departemen Teknologi Hasil Perairan. FPIK IPB, Bogor.

Kartasapoetra, A.G, 1999, Teknologi Penanganan Pasca Panen, PT. Rhineka Cipta, Jakarta.

Kuswuri,R., 2012, Pengertian Pol, Brix dan HK dalam Analisis Gula,http://www.risvank.com/tag/b rix/, diakses tanggal 12 September 2013.

Labuza, T.P., 2000. Determination of the Shelf Life of Foods. http://www.faculty.che.umn.edu/f scn. [15 Desember 2008].

Meidina, Sugyono, Jenie, B.S.L. Suhartono, M.T. 2005. Aktifitas Antibakteri Oligomer Kitin yang Diproduksi Menggunakan Kitin Dari Isolat B. licheniformis MB2. Departemen Teknologi Pangan dan Gizi. Institut Pertanian Bogor. Bogor.

Maulida Rachmawati. 2010. Pelapisan Chitosan pada Buah Salak Pondoh.

http://jtpunmul.files.wordpress.co $\mathrm{m} / 2011 / 06 /$ sopian-hadi.pdf. diakses 25 Maret 2013.

Muchtadi D. 1992, Fisiologi Pasca Panen Sayuran dan Buah-buahan, Pusat Antar Universitas Pangan dan Gizi, Institut Pertanian Bogor, Bogor.

Prabawati S, Tranggono dan Mulyoharjo, M, 1991, Karakteristik Cendawan Penyebab Kerusakan Buah Duku (Lansium domesticum Corr), Jurnal Hortikultura, 1: 28.

Raafat D, von Bargen K, Haas A, Sahl HG. 2008. Insights into the mode of action of chitosan as an antibacterial compound. Appl Environ Microbial.

Widodo (2005, Widodo SE. 2005, Bahan Penyerap $\mathrm{KMnO} 4$ dan Asam Laskorbat dalam Pengemas Aktif 
(Active Packaging) untuk Memperpanjang Masa Simpan dan Mempertahankan Buah Duku, Jurnal Teknologi dan Industri Pangan 2(16): 113.Winarno, F.G.,2002, Fisiologi Lepas Panen Produk Hortikultura, M-Brio Press, Bogor.

Winarno,F.G., 2004, Kimia Pangan dan Gizi, PT. Gramedia Pustaka Utama, Jakarta.
Winarno, F.G dan M. Aman, 2002., Fisiologi Lepas Panen, Sustra Hudaya, Bogor.

Yusnaidar, 2009, Sifat Kimia dan Fisika Buah Duku Asal Batanghari pada Berbagai Tingkat Kematangan, Jurnal Kimia Universitas Jambi, Vol.I (2). 